\title{
It's Not Always Appendicitis: Relatively Uncommon Conditions of Acute Abdomen in Children
}

\section{Her Zaman Apandisit Değildir: Çocuklarda Daha Nadir Görülen Akut Karın Nedenleri}

\author{
Berat Dilek Demirel', @Beytullah Yağız' \\ 'Ondokuz Mayıs University, School of Medicine, Department of Pediatric Surgery, Samsun, Turkey
}

\begin{abstract}
Aim: To evaluate the acute surgical conditions beyond acute appendicitis in children.

Material and Method: The children who underwent urgent abdominal surgery between January 2017-December 2020 are retrospectively evaluated. The newborns and patients with acute appendicitis are excluded.

Results: A total of 595 patients underwent urgent abdominal surgery. Acute appendicitis was the final diagnosis in 468 of them (78.7\%). The median age of the rest of the 127 patients (21.3\%) was 8 years (0.96-17.75 years). Fourteen patients admitted with trauma (11\%) (12 boys and 2 girls, median age; 12.66 years), and the most common cause was firearm injuries with the most common injured system was the gastrointestinal system. Among the patients without trauma, 62 were boys (54.6\%) and 51 were girls (45.1\%) (median age; 6.41 years). Intussusception was most common in the Infant and Young Child Group. Adhesive small bowel obstruction was most common in adolescent boys and the Child Group while adnexal torsion was most common in adolescent girls. Intussusception, adhesive small bowel obstruction and gastrointestinal perforation were encountered in all age groups

Conclusion: Although acute appendicitis is the most common cause of acute abdomen in children, other causes are not uncommon and some need special attention as differential diagnosis and intervention are "more urgent" than others. Awareness of these "more urgent" conditions with respect to age groups may prevent complications, morbidity, and even mortality.
\end{abstract}

Keywords: Abdomen, acute, intussusception, adnexal torsion, intestinal obstruction
Öz

Amaç: Çocuklarda akut apandisit dışı akut cerrahi nedenlerin değerlendirilmesi.

Gereç ve Yöntem: Ocak 2017- Aralık 2020 tarihleri arasında acil karın cerrahisi yapılan çocuk hastalar retrospektif olarak değerlendirildi. Yenidoğan dönemindeki hastalar ve apandisit nedeniyle ameliyat edilen hastalar çaışma dışı bırakıldı.

Bulgular: 595 hastaya acil abdominal cerrahi yapıldı. 468'inde $(\% 78,7)$ kesin tanı apandisitti. Apandisit dışı nedenle ameliyat edilen 127 hastanın $(\% 21,3)$ ortanca yaşı $8(0,96-17,75)$ yıldı. Travma ile başvuran 14 (\%11) hasta vardı (12 erkek, 2 kız, ortanca yaş; 12,66 yıl). En sık travma nedeni ateşli silah yaralanması ve en sık yaralanma gastrointestinal sistemde yaralanmasıydı. Nontravmatik Grupta 62 (\%54,6) hasta erkek ve 51 (\%45,1) hasta kızdı ( ortanca yaş; 6,41 yı)). Infantlarda ve küçük çocuklarda en sık invajinasyon görüldü. Ergen erkeklerde ve Çocuk Grubunda en sık adhesiv barsak tıkanıklığı görülürken, ergen kızlarda en sık adneksiyal torsiyon görüldü. İnvajinasyon, adhesiv barsak tıkanıklığı ve gastrointestinal perforasyon tüm yaş gruplarında görüldü.

Sonuç: Çocuklarda en sık akut karın nedeni akut apandisit olsa da, diğer nedenler de nadir değildir ve ayırıcı tanı ve müdahalenin "daha acil" olması nedeniyle dikkat edilmelidir. Yaş gruplarına göre bu "daha acil" durumların farkında olunması komplikasyonları, morbiditeyi ve hatta mortaliteyi önleyebilir.

Anahtar Kelimeler: Karın, akut, intususepsiyon, adneksiyal torsiyon, barsak tıkanıklığı 


\section{INTRODUCTION}

The management of acute abdominal pain in children is challenging as the differential diagnosis of acute abdomen involves many medical and surgical conditions depending on the age groups. ${ }^{[1]}$ As the most common surgical condition in children, acute appendicitis is commonly used as a synonym of acute abdomen. ${ }^{[2]}$ However, other causes of the acute abdomen are not infrequent in children and differential diagnosis and intervention is more urgent than acute appendicitis as they may cause significant morbidity and mortality if recognition or intervention are delayed. ${ }^{[3]}$ Acute abdomen is a relatively vague term which is used for a range of conditions, and a definitive diagnosis may not even be achieved by radiological and laboratory evaluations in some. In such a patient presenting with abdominal pain, vomiting and fever triad, surgical exploration may be needed to rule out or confirm a surgical condition. ${ }^{[4]}$ The decision for the timing and urgency of the surgical intervention is critical when evaluating a child presenting with findings of the acute abdomen to prevent unnecessary interventions and to reduce morbidity and mortality. ${ }^{[3]}$ The first clue for the differential diagnosis of children with acute abdomen may be the patients' age and even gender. In this study, our aim is to evaluate the surgical emergencies other than acute appendicitis in different age groups in children.

\section{MATERIAL AND METHOD}

The children ( $\leq 18$ years) who underwent urgent abdominal surgery between January 2017-December 2020 in a tertiary referral center are enrolled in the study. Newborns (0-30 days old) and patients with acute appendicitis are excluded from the final analyses. Patients' age, gender, indication of the surgery, morbidity, and mortality are retrospectively evaluated. Patients were divided into subgroups according to age, as Infant (1 month- 2 years), Young Child (2-6 years), Child (6-12 years), and Adolescent ( $>12$ years) proposed by World Health Organization.

For descriptive statistical analysis, median, minimum and maximum values, frequency and percentage values were calculated. Kolmogorov-Smirnov test was used to evaluate for normal distribution of the variables and Kruskal Wallis test (Mann-Whitney U test for pairwise comparison) was used for the comparison of the quantitative data. Qualitative variables were analyzed by the Chi-Square test. SPSS ${ }^{\circledR} 22.0$ program (IBM Corp., Armonk, NY, USA) was used for statistical analyses. A p-value $<0.05$ was considered statistically significant.

\section{RESULTS}

During the study period, 595 patients had undergone urgent abdominal surgery excluding the newborns. Acute appendicitis was the most common indication $(78.7 \%$; $\mathrm{n}=468)$ encountered in 305 boys (65.2\%) and 163 girls (34.8\%) with a median age of 11.08 years (0.67-17.91 years). When acute appendicitis was excluded, the study group comprised of 74 boys (58.3\%) and 53 girls (41.7\%) with a median age of 8 years
(0.96-17.75 years). Gender distribution was similar between the 2 groups but the median age was significantly lower in the non-appendicitis patients $(\mathrm{p}=0.000)$.

Fourteen patients (11\%) with a median age of 12.66 years (5.2517.58 years) were operated for abdominal trauma; 12 were boys and 2 were girls. In total, 62 boys (54.6\%) and 51 girls (45.1\%) were operated for indications other than trauma and acute appendicitis with a median age of 6.41 years (0.96-17.75 years). Male gender and median age were significantly higher in the patients operated for trauma $(p=0.027$ and $p=0.04$, respectively).

The most common cause of abdominal trauma was firearm injuries. Trauma patients were young children $(n=1)$, children $(n=6)$ or adolescents $(n=7)$, and the most common injury was gastrointestinal perforation (Table 1). Two patients with trauma were deceased (14.3\%); an 8 years old girl involved in a motor vehicle accident with multi-organ injuries and an 11.5 years old boy with intracranial bleeding who fell from a high place. Right nephrectomy was performed in another 13,5 years old boy. No other mortality or major organ loss was observed in any other trauma patient.

\begin{tabular}{|c|c|c|c|c|}
\hline Patient & $\begin{array}{c}\text { Age } \\
\text { years }\end{array}$ & Gender & Trauma & Involved organ \\
\hline 1 & 17.50 & boy & Firearm injury & liver-diaphragma \\
\hline 2 & 14.75 & boy & $\begin{array}{l}\text { Penetrating } \\
\text { stab injury }\end{array}$ & liver-diaphragma \\
\hline 3 & 8.00 & girl & $\begin{array}{l}\text { Motor vehicle } \\
\text { accident }\end{array}$ & $\begin{array}{l}\text { stomach-duodenum- } \\
\text { jejunum-ovaries-ureter }\end{array}$ \\
\hline 4 & 11.25 & boy & Firearm injury & liver-pancreas \\
\hline 5 & 17.58 & boy & $\begin{array}{l}\text { Motor vehicle } \\
\text { accident }\end{array}$ & duodenum-jejunum \\
\hline 6 & 11.58 & boy & $\begin{array}{c}\text { Fall from a high } \\
\text { level }\end{array}$ & jejunum \\
\hline 7 & 5.25 & boy & Firearm injury & liver-duodenum \\
\hline 8 & 15.91 & boy & $\begin{array}{l}\text { Motor vehicle } \\
\text { accident }\end{array}$ & diaphragma \\
\hline 9 & 10.50 & boy & Bicycle accident & ileum \\
\hline 10 & 13.75 & boy & Firearm injury & $\begin{array}{l}\text { liver-kidney-duodenum- } \\
\text { jejunum-colon-choledochus }\end{array}$ \\
\hline 11 & 9.08 & girl & Firearm injury & ileum \\
\hline 12 & 14.66 & boy & Firearm injury & colon-ileum \\
\hline 13 & 15.58 & boy & Firearm injury & none \\
\hline 14 & 11.50 & boy & $\begin{array}{l}\text { Fall from a high } \\
\text { level }\end{array}$ & none \\
\hline
\end{tabular}

Intussusception was the most common indication for urgent abdominal surgery after acute appendicitis and trauma. All patients with intussusception underwent surgery after at least one failed attempt of hydrostatic reduction. Intussusception was the most common indication of surgery in infants and young children. Adhesive small bowel obstruction was the most common cause in children and adolescent boys while adnexal torsion was most common in adolescent girls (Table 2). No definitive diagnosis could be achieved in 6 patients (5.3\%) even after surgical exploration. Although distribution was heterogenous, intussusception, adhesive small bowel obstruction and gastrointestinal perforation were encountered in all of the age groups (Figure 1). 
Table 2. Age distribution of the children who underwent urgent surgery for reasons other than trauma and acute appendicitis.

\begin{tabular}{|c|c|c|c|c|c|}
\hline & Infant & $\begin{array}{l}\text { Young } \\
\text { children }\end{array}$ & Children & Adolescent & Total \\
\hline Intussusception & 15 & 9 & 6 & 2 & 32 \\
\hline Adnexal torsion & 0 & 1 & 5 & 12 & 18 \\
\hline $\begin{array}{l}\text { Incarcerated } \\
\text { diaphragmatic } \\
\text { hernia }\end{array}$ & 3 & 1 & 0 & 0 & 4 \\
\hline $\begin{array}{l}\text { Strangulated } \\
\text { inguinal hernia }\end{array}$ & 3 & 0 & 0 & 0 & 3 \\
\hline $\begin{array}{l}\text { Meckel's } \\
\text { diverticulum }\end{array}$ & 0 & 2 & 0 & 2 & 4 \\
\hline $\begin{array}{l}\text { Adhesive small } \\
\text { bowel obstruction }\end{array}$ & 2 & 5 & 7 & 7 & 21 \\
\hline $\begin{array}{l}\text { Gastrointestinal } \\
\text { perforation }\end{array}$ & 4 & 1 & 2 & 7 & 14 \\
\hline Volvulus & 4 & 1 & 0 & 0 & 5 \\
\hline $\begin{array}{l}\text { Gallbladder } \\
\text { perforation }\end{array}$ & 0 & 0 & 0 & 1 & 1 \\
\hline Internal herniation & 0 & 0 & 0 & 1 & 1 \\
\hline Colonic stricture & 2 & 0 & 0 & 0 & 2 \\
\hline Colon tumor & 0 & 0 & 0 & 1 & 1 \\
\hline Duplication cyst & 0 & 0 & 1 & 0 & 1 \\
\hline $\begin{array}{l}\text { Negative } \\
\text { exploration }\end{array}$ & 2 & 0 & 1 & 3 & 6 \\
\hline Boys/Girls & $28 / 7$ & $10 / 10$ & $8 / 14$ & $16 / 20$ & $62 / 51$ \\
\hline Total & $\begin{array}{c}35 \\
(31 \%)\end{array}$ & $\begin{array}{c}20 \\
(17.7 \%)\end{array}$ & $\begin{array}{c}22 \\
(19.5 \%)\end{array}$ & $\begin{array}{c}36 \\
(31.9 \%)\end{array}$ & 113 \\
\hline
\end{tabular}

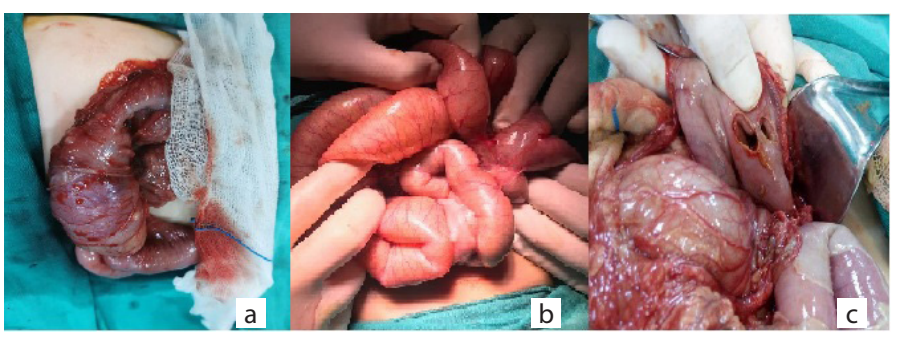

Figure 1. a: lleo-colic intussusception. b: Adhesive small bowel obstruction due to previous abdominal surgery. c: Stomach perforation secondary to peptic ulcer.
Strangulated inguinal hernia and colonic stricture secondary to necrotizing enterocolitis (NEC) were seen only in infants while volvulus and incarcerated diaphragmatic hernia were only in infants and young children. Adnexal torsion was encountered in young children, children and adolescents while internal herniation (due to congenital band), gallbladder perforation and colonic obstruction (due to tumor) were encountered only in adolescents (Figure 2). With respect to underlying neoplastic conditions, a child had Burkitt's Lymphoma (intussusception) and another had rhabdomyosarcoma (jejunal perforation due to tumor invasion) while an adolescent had colonic adenocarcinoma (colonic obstruction) and another had an ovarian dermoid tumor (ovarian torsion).

When patients with trauma were excluded, 4 patients were deceased in the perioperative period; an infant with intestinal perforation secondary to NEC, a young child with adhesive small bowel obstruction who had previous multiple abdominal operations, a child with gastric perforation (with co-existing chronic kidney failure) and an adolescent with multiple intestinal perforations of unknown etiology. Two patients (rhabdomyosarcoma and colonic adenocarcinoma, respectively) were deceased due to malignancy during follow-up after the operation. The mortality rate was $14 \%$ $(2 / 14)$ in patients with trauma and $5 \%(6 / 113)$ in the rest of the patients.

\section{DISCUSSION}

Abdominal pain is one of the most common complaints for hospital admittance in childhood and is a benign process in most instances ${ }^{[5]}$ However, among this crowded population, some patients require special attention as they need to be identified and managed appropriately and urgently due to the emergency of their disease process. The identification of these patients is challenging and even a diagnostic surgical exploration may be necessary for some as laboratory, clinical and radiological evaluations remain inconclusive. ${ }^{[6]}$ Although acute appendicitis is the most common urgent surgical condition in children, there are more urgent conditions in children that can not wait to see the sunrise. ${ }^{[3]}$ Differential diagnosis of these conditions is challenging and delay in diagnosis may cause significant morbidity and even mortality. ${ }^{[7]}$

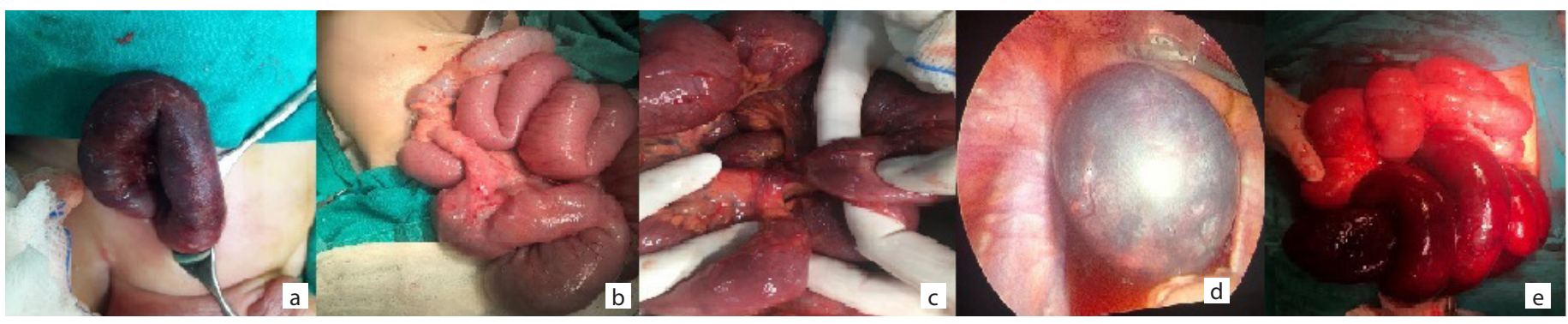

Figure 2. a: Strangulated inguinal hernia. b: Colonic stricture due to previous NEC and secondary ileal dilation. c: Internal herniation due to congenital band d. Ovarian torsion e. Intestinal ischemia and necrosis due to volvulus. 
Although rare, abdominal trauma is a significant cause of morbidity and mortality in children. Although the majority are spleen or liver injuries due to blunt trauma that can be managed conservatively in most cases, penetrating firearm and/or stab injuries are not so uncommon and are more likely to require surgical intervention. ${ }^{[8,9]}$ In our series, 8 of the 14 trauma patients had penetrating injuries. Although blunt trauma can be seen in all age groups, penetrating trauma is much more prevalent in adolescents. ${ }^{[10]}$ In our series, all of the urgent interventions for trauma were in the Child and Adolescent Groups, and the median age was 2 fold higher than the patients operated for other reasons.

The most common reason for urgent surgery in children is acute appendicitis ${ }^{[11]}$ and constituted $78.7 \%$ of the patients who received urgent abdominal surgery in our series. Although surgical emergencies beyond trauma and acute appendicitis are relatively rare in children, related morbidity and mortality are relatively high. ${ }^{[12]}$ Diagnosis of medical conditions is challenging in children as poor verbal cooperation limits the valuable information obtained by history, which is more prominent in younger ages. Especially in infants, patients may admit with vague symptoms like persistent crying, refusal of feeding or restlessness. ${ }^{[13]}$ Differential diagnosis is essential to determine the urgency of the surgical intervention as some conditions like acute appendicitis may wait for the sunrise while others better not. The indications of urgent surgery in infants include intussusception, strangulated inguinal hernia, volvulus, complicated Meckel's diverticulum and adhesive small bowel obstruction due to previous surgeries. ${ }^{[14]}$ Acute abdominal surgery is least common in young children ${ }^{[12,15]}$ and our results also indicate the same finding. Although young children may express their complaints and be more cooperative while story taking, they usually cooperate poorly during physical examination. ${ }^{[16]}$

In our study, intussusception was the most prevalent condition in infants and young children. Currently, non-surgical management is the first-line option for intussusception and commonly hydrostatic reduction under ultrasonography or fluoroscopy is commonly performed with success rates around 90\%. ${ }^{[17,18]}$ Intussusception was the surgical indication in 24 of the 55 infants and young children in our series, and all underwent operation after at least one failed attempt of hydrostatic reduction. Although most cases can be managed without surgery, some require surgical correction and delay in diagnosis and treatment may cause loss of a significant amount of intestine and even result in mortality. ${ }^{[19]}$

Volvulus is also a rare but serious condition in which prompt diagnosis and correction are essential in order to prevent significant morbidity and mortality. Although most present during the newborn period, about $30 \%$ may present later in life. ${ }^{[20]}$ In our study, 1 of the 5 patients with volvulus was a young child and the rest were infants.
An incarcerated inguinal hernia is a common condition in children, and usually can be reduced manually by experienced hands obviating an urgent surgical intervention. ${ }^{[21]}$ Urgent surgery is indicated when hernia can not be reduced and intestinal resection may be necessary in a minority of cases due to compromised blood flow of the incarcerated segment. ${ }^{[22]}$ In our series, only 3 infants required urgent surgery for an incarcerated hernia.

Complicated Meckel's Diverticulum, adhesive small bowel obstruction, adnexal torsion are the common urgent surgical conditions in the Child age group after acute appendicitis. ${ }^{[23]}$ In our study, adhesive small bowel obstruction was the most common condition in this age group and intussusception remained a significant cause of surgical intervention.

Adnexal torsion can be seen in the Child and Adolescent age groups and although rare, can cause organ loss and even compromise fertility if diagnosis and intervention are delayed. ${ }^{[24]}$ As the uterine adnexa resides in the pelvis, these patients may present with non-specific symptoms and clinical findings may be vague; therefore, children and adolescent girls presented with acute abdomen should be carefully evaluated for adnexal torsion. ${ }^{[25,26]}$ In our study, five of the 14 girls in the Child Group and 12 of the 20 girls in the Adolescent Group underwent surgery for adnexal torsion.

Adhesive small bowel disease can be seen in $1-9 \%$ of the patients with a previous history of abdominal surgery and more than $50 \%$ can be managed by conservative approach. A small portion of patients may require surgery due to failed conservative management. ${ }^{[27]}$ Beyond trauma and acute appendicitis, adhesive small bowel disease was the second most common cause of urgent surgery after intussusception in our study. Although prevalent in all age groups, it was the most common surgical condition in the Child Group and adolescent boys.

The incidence of peptic and gallbladder diseases appear to increase in recent years, possibly due to changing trends in eating habits. ${ }^{[28]}$ Peptic diseases are reported to be the most common cause of non-traumatic stomach perforations in children and gastric perforation was most common in adolescent patients. ${ }^{[29]}$ Similarly, gastrointestinal perforation incidence was higher in adolescents in our series and we have encountered a very rare case of gallbladder perforation in an adolescent.

Despite amazing developments in medical knowledge and diagnostic technology, the final diagnosis can be achieved after surgical exploration in a significant amount of patients ${ }^{[6]}$ Even so, some of these explorations do not reveal a surgical cause but may help to exclude a surgical cause to re-direct the diagnostic process. In our study, we also could not be able to reach a final diagnosis even after surgical exploration in 2 patients with trauma and 6 patients with non-traumatic acute abdomen. 


\section{CONCLUSION}

Although acute appendicitis is the most common cause of acute abdomen in children, a significant rate of patients suffer from other conditions. The incidence of these other conditions vary among age groups and appropriate and timely diagnosis requires knowledge and familiarity by the clinician and the radiologist. Although delay in differential diagnosis may cause morbidity and even mortality, rushing to the operation room may also increase the rate of unnecessary interventions or complications.

\section{ETHICAL DECLARATIONS}

Ethics Committee approval: This study was approved by Ethic Committee of Ondokuz Mayis University (IRB approval number:2020/711).

Informed Consent: Because the study was designed retrospectively, no written informed consent form was obtained from patients.

Conflict of Interest Statement: The authors have no conflicts of interest to declare.

Financial Disclosure: The authors declared that this study has received no financial support.

\section{REFERENCES}

1. Duman M, Yılmaz D, Akgül F et al. Çocuk Acil Servisine Akut Karın Ağrısı ile Başvuran Olgularda Klinik Bulguların Yeri. CAYD 2015;2(2):77-82.

2. Stringer MD. Acute appendicitis. J Paediatr Child Health 2017;53:1071-6.

3. Balachandran B, Singhi S, Lal S. Emergency management of acute abdomen in children. Indian J Pediatr 2013;80(3):226-34.

4. Taşar S, Taşar MA, Güçer L et al. The importance of the history and laboratory tests in the differential diagnosis of acute abdominal pain cases in the pediatric emergency department Turkish J Pediatr Dis 2015;1:27-31

5. Tekgündüz SA, Şengül A, Biçer S et al. Çocuk acil servisine akut karın ağrısı yakınmasıyla getirilen olguların analizi. Bakırköy Tıp Derg 2005;1(2):52-6.

6. Ilce Z, Yildiz T, Isleyen M. The role of laparoscopy in suspicious abdomen pain in children. Pak J Med Sci 2013;29(4):1042-5.

7. Hijaz NM, Friesen CA. Managing acute abdominal pain in pediatric patients: current perspectives. Pediatric Health Med Ther 2017;8:83-91.

8. Hegde S, Bawa M, Kanojia RP et al. Pediatric trauma: management and lessons learned. J Indian Assoc Pediatr Surg 2020;25(3):142-6.

9. Lynch T, Kilgar J, Al Shibli A. Pediatric abdominal trauma. Curr Pediatr Rev 2018;14(1):59-63.

10. Arslan S, Okur MH, Arslan MS et al. Management of gastrointestinal perforation from blunt and penetrating abdominal trauma in children: analysis of 96 patients. Pediatr Surg Int 2016;32(11):1067-1073.

11. Glass CC, Rangel SJ. Overview and diagnosis of acute appendicitis in children. Semin Pediatr Surg 2016;25(4):198-203.

12. Yang WC, Chen CY, Wu HP. Etiology of non-traumatic acute abdomen in pediatric emergency departments. World J Clin Cases 2013;1(9):276-84.

13. El Hasbaoui B, Karboubi L, Benjelloun BS. The role of abdominal ultrasound in the management of excessive crying in infants. Pan Afr Med J 2018;30:68.

14. Naffaa L, Barakat A, Baassiri $A$ et al. Imaging acute non-traumatic abdominal pathologies in pediatric patients: A pictorial review. J Radiol Case Rep 2019;13(7):29-43.
15. Sakita FM, Sawe HR, Mwafongo V et al. The burden and outcomes of abdominal pain among children presenting to an emergency department of a tertiary hospital in Tanzania: A Descriptive Cohort Study. Emerg Med Int 2018;2018:3982648.

16. Kuppermann N, O'Dea T, Pinckney L et al. Predictors of intussusception in young children. Arch Pediatr Adolesc Med 2000;154(3):250-5.

17. Tander B, Baskin D, Candan M et al. Ultrasound guided reduction of intussusception with saline and comparison with operative treatment. Ulus Travma Acil Cerrahi Derg 2007;13(4):288-93.

18. Özcan R, Hüseynov M, Emre Ş et al. A review of intussusception cases involving failed pneumatic reduction and re-intussusception. Ulus Travma Acil Cerrahi Derg 2016;22(3):259-64.

19. Pindyck T, Parashar U, Mwenda JM, et al. Risk factors associated with increased mortality from intussusception in African infants. J Pediatr Gastroenterol Nutr 2020;70(1):20-4.

20. Palanivelu C, Rangarajan M, Shetty AR et al. Intestinal malrotation with midgut volvulus presenting as acute abdomen in children: value of diagnostic and therapeutic laparoscopy. J Laparoendosc Adv Surg Tech A 2007;17(4):490-2.

21. Olesen CS, Mortensen LQ, Öberg S et al. Risk of incarceration in children with inguinal hernia: a systematic review. Hernia. 2019;23(2):245-54.

22. Zamakhshary M, To T, Guan J et al. Risk of incarceration of inguinal hernia among infants and young children awaiting elective surgery. CMAJ 2008;179(10):1001-5.

23. Tseng YC, Lee MS, Chang YJ et al. Acute abdomen in pediatric patients admitted to the pediatric emergency department. Pediatr Neonatol 2008;49(4):126-34.

24. Adeyemi-Fowode O, McCracken KA, Todd NJ. Adnexal Torsion. J Pediatr Adolesc Gynecol 2018;31(4):333-8.

25. Smorgick N, Nir O, Pekar-Zlotin M et al. Long-term ultrasound follow-up after pediatric adnexal torsion. Ultraschall Med 2020;41(4):404-9.

26. Demirel BD, Hancıoğlu S, Bicakci U et al. Complications of Meckel's diverticulum in children: A 10-years experience. J Exp Clin Med 2020;36(3): 67-71.

27. Lin LH, Lee CY, Hung MH et al. Conservative treatment of adhesive small bowel obstruction in children: a systematic review. BMJ Open 2014 Sep 15;4(9):e005789.

28. Rothstein DH, Harmon CM. Gallbladder disease in children. Semin Pediatr Surg 2016;25(4):225-31.

29. Hua MC, Kong MS, Lai MW et al. Perforated peptic ulcer in children: a 20year experience. J Pediatr Gastroenterol Nutr 2007;45(1):71-4. 